\title{
In memoriam \\ Juana Gutiérrez Haces \\ (1948-2007)
}

Mueran contigo, Laura, pues moriste, los afectos que en vano te desean, los ojos a quien privas de que vean hermosa luz que un tiempo concediste.

Muera mi lira infausta en que influiste Ecos, que lamentables te vocean $Y$ hasta estos rasgos mal formados sean lágrimas negras de mi pluma triste.

Sor Juana Inés de la Cruz

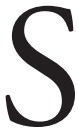
E Ha APAgado UNA VOZ, una voz que centraba y compartía, que enseñaba y convencía, una voz sonora y firme. Se ha quebrado una pluma, una pluma que combatía y argumentaba, que iluminaba y debatía. Se ha parado un corazón, un corazón compasivo y amoroso, enérgico y entregado. Juana Gutiérrez ha muerto y nos ha dejado un vacío. Esta mujer excepcional era ante todo una maestra, una docente que con claridad y paciencia impartió los cursos de Renacimiento y Siglo xviri en la Facultad de Filosofía y Letras en la Universidad Nacional Autónoma de México, de Historia y Teoría del Arte en la Escuela de Artes Plásticas de San Carlos y de Arte colonial en numerosos diplomados. Desde 1972 hasta tres meses antes de su lamentable deceso, a lo largo de 35 años de labor docente ininterrumpida, Juana formó a varias 
generaciones de jóvenes y no tan jóvenes, enseñó a percibir el arte como fenómeno estético e histórico, los llevó a apreciar el objeto artístico y a enriquecerlo con su contextualización. Sus clases estaban siempre llenas, había gente que se sentaba en el suelo pues se había hecho fama la excepcionalidad de su exposición. Inscritos y oyentes escuchaban embelesados los conceptos y observaban las imágenes que seleccionaba minuciosamente para ilustrar cada lección. Juana amaba dar clases, al subir a la tarima se transformaba en una maga que transportaba a sus oyentes a otros países y a otras épocas. Sus estudios como normalista primero y después en la Facultad de Filosofía y Letras potenciaron su formación magisterial, que sin embargo llevaba como base una vocación docente innata. Gracias a sus estudios en Italia y a su sólida preparación en el arte europeo, llenaba con sus clases un área en la que hay muy pocos especialistas en México. Su ausencia ha dejado un vacío en este campo.

Juana era también una investigadora de alto nivel. Su tesis de licenciatura sobre el Palacio de Comunicaciones es ya una referencia obligada para todo aquel que se dedica a la arquitectura porfiriana. Su tesis de doctorado en Italia sobre el jesuita Pedro José Marques y sus teorías estéticas estaba siendo preparada para su publicación, al igual que el diccionario de arquitectura que dejó escrito este autor. Fue inspiradora y coordinadora de un libro sobre el pintor Cristóbal de Villalpando que marcó pautas para el estudio de la pintura virreinal. Su proyecto para realizar dos antologías de textos y documentos sobre el arte en el imperio español convocó a investigadores de España y América en una importante visión de conjunto. A su muerte dejó inconclusos, pero muy avanzados, dos proyectos: la pintura de los reinos, una obra colectiva que dará mucha luz sobre las coincidencias y diferencias, tanto plásticas como iconográficas, entre los diferentes reinos que formaban el imperio español, y los fenómenos de circulación de modelos y personas que reforzaban los lazos de unión en esa enorme comunidad cultural. Su segundo proyecto, la generación de pintores contemporáneos de la Maravilla americana ... de Cabrera, era una investigación personal que preparaba como tesis de doctorado y como guión museográfico para una magna exposición en la que dialogarían las obras de esos artistas que vivieron a caballo entre la era barroca y la ilustrada. Su muerte ha dejado aquí también un vacío, la visión de una época y de una cultura poco estudiadas hasta ahora (la primera mitad del siglo XviII novohispano) extrañará las ideas que se llevó y que nunca pudo concluir.

Por otro lado, Juana también era una extraordinaria difusora de la cultura. Como asesora y consultora de Fomento Cultural Banamex, fue la inspiradora 
I. Maestra Juana Gutiérrez Haces. Archivo personal de Rosario Gutiérrez Haces.

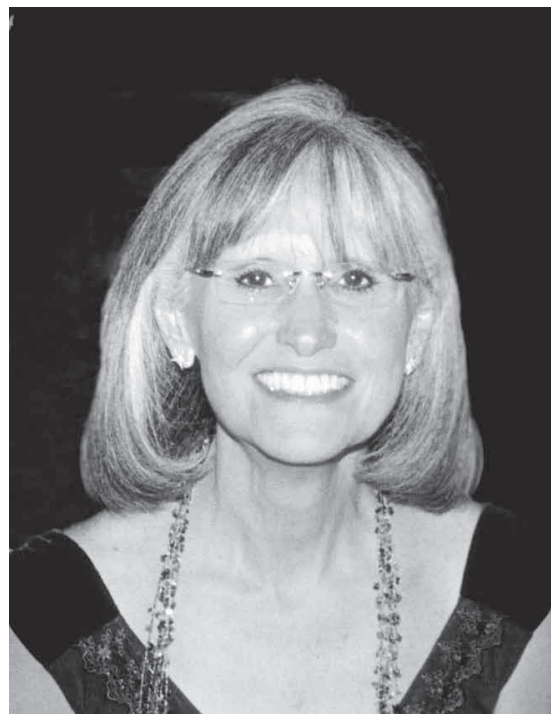

de numerosas exposiciones que quedaron plasmadas en fascinantes catálogos, recomendó la adquisición de obras para la colección del banco, revisó textos y coordinó investigaciones. Fue también autora de guiones museográficos en el Museo Nacional de Arte y en numerosas exposiciones en varios museos de la capital y del país. Colaboró asimismo en la labor editorial de revistas, actas de coloquios y en la coordinación de seminarios internacionales. Era una excepcional expositora también en paseos culturales y visitas guiadas, poseía una especial sensibilidad para trasmitir con claridad y pasión el amor por los objetos artísticos y por la riqueza de nuestro patrimonio. Todos los que la escuchamos extrañaremos sus lúcidas exposiciones, su ameno discurso. Aquí también nos ha dejado un vacío.

Juana, en fin, era una académica excepcional pero muchos también la recordamos como una amiga entrañable, como una conversadora divertida y jovial, como la abogada de los débiles, como amante apasionada de la naturaleza, de la jardinería, como una ciudadana del mundo, viajera incansable con quien uno podía recorrer fascinado ciudades, museos e iglesias y perder la conciencia del tiempo. La recordamos como una colega que defendía la justicia y la equidad, como una mujer apasionada, que vivía con intensidad sus vocaciones de maestra, investigadora y difusora, como una persona profundamente comprometida 
con la universidad, en la que participó activamente en varios cuerpos colegiados, como una ciudadana ejemplar preocupada por los problemas de su país y del mundo. En nosotros, sus amigos, Juana ha dejado, pienso, el mayor vacío de todos, aquel que no tiene solución. Otros maestros ocuparán sus cátedras, otros investigadores se avocarán al estudio de los pintores que ella no pudo concluir, otros difusores asesorarán sus exposiciones y darán sus conferencias, pero nadie podrá sustituirla en el afecto que supo ganarse con su atrayente y multifacética personalidad, con su afabilidad y fortaleza, con su calidad humana. Extrañaremos ese amor que mostró por todos nosotros y cuya ausencia nos hace sentir que alguien insustituible nos ha dejado. \$ 